\title{
PENGARUH POSISI CENTERBULB BERBENTUK FOIL TERHADAP KOMPONEN HAMBATAN KAPAL IKAN KATAMARAN MV. LAGANBAR
}

\author{
Muhammad Iqbal*, Parlindungan Manik*, Eko Sasmito Hadi*, and Achmad Kurniawan* \\ * Diponegoro University \\ Department of Naval Architecture \\ Jl. Prof. Soedarto, SH - Tembalang, Semarang 50275, Indonesia \\ E-mail:m_iqbal@live.undip.ac.id
}

\begin{abstract}
Abstrak
Kapal katamaran adalah kapal berlambung ganda yang mempunyai banyak keunggulan dibandingkan kapal berlambung tunggal dengan displasemen yang sama. Untuk meningkatkan hasil tangkapan, para nelayan di Cilacap melakukan konversi salah kapal dari semula lambung tunggal dengan cadik menjadi katamaran. Displasemen kapal meningkat 2 kali lipatnya. Namun hambatan kapal meningkat hingga hampir 4 kali lipatnya. Untuk mengurangi hambatan kapal katamaran beberapa peneliti menggunakan konsep centerbulb. Pada penelitian ini, bentuk centerbulb yang digunakan bentuk foil. Tujuan dari penelitian ini adalah untuk mengetahui pengaruh posisi centerbulb terhadap komponen hambatan kapal dengan membandingkan 9 posisi centerbulb. Hasil penelitian menyatakan bahwa dari kesembilan konfigurasi posisi centerbulb, Model 6, posisi memanjang centerbulb 4,5 m dan posisi vertikal 0,35 m, merupakan model terbaik karena Pada Fr (Froude Number) 0,35 dapat mengurangi hambatan kapal hingga 33\%. Untuk komponen hambatan viskos tidak terlalu terpengaruh secara signifikan terhadap penggunaan centerbulb. Namun pada komponen hambatan gelombang, penggunaan centerbulb ini dapat mengurangi hambatan gelombang sebesar $47 \%$ pada $\mathrm{Fr} 0,35$.
\end{abstract}

Kata kunci: Hambatan, Katamaran, Centerbulb , Foil, CFD

\section{Abstract}

Catamarans are double hull ships which have many advantages over single hull ships with the same displacement. To increase catches, fishermen in Cilacap converted ships from the original single hull with outrigger to double hull (catamaran). Displacement of ships has doubled. But the ship's resistance increased to almost 4 times. To reduce the resistance of catamarans, some researchers use the concept of centerbulb. In this study, the centerbulb form used foil. The purpose of this study was to determine the effect of centerbulb position on ship resistance components by comparing 9 centerbulb positions. The results stated that of the nine centerbulb position configurations, Model 6, longitudinal position of 4,5 $\mathrm{m}$ and vertical position of $0.35 \mathrm{~m}$, is the best model because at Fr (Froude Number) 0.35 it can reduce ship resistance by up to 33\%. For the viscous resistance component it is not significantly affected by the use of the centerbulb. But on the wave resistance component, the use of this centerbulb can reduce wave resistance by $47 \%$ at $\mathrm{Fr} 0.35$.

Keywords: Resistance, Catamarran, Centerbulb, Foil, CFD

\section{Introduction}

Kapal katamaran adalah kapal berlambung ganda yang mempunyai banyak keunggulan dibandingkan kapal berlambung tunggal dengan displasemen yang sama. Diantara keunggulan tersebut adalah kapal katamaran mempunyai geladak yang luas sehingga desainer lebih leluasa dalam menata ruang akomodasi kapal. Selain itu kapal katamaran mempunyai stabilitas kapal yang baik sehingga kapal katamaran lebih aman dan nyaman bagi penumpang [1, 2]

Di Indonesia, hampir seluruh kapal ikan tradisional mengunakan lambung tunggal (monohull). Untuk meningkatkan hasil tangkapan, para nelayan di Cilacap melakukan konversi salah satu kapal nelayan tradisional yang bernama Laganbar dari semula lambung tunggal dengan cadik menjadi katamaran. Dalam mengkonversi kapal tersebut, nelayan Cilacap mempertahankan nilai sarat kapal (T) sehingga 
displasemen kapal meningkat 2 kali lipatnya. Namun, berdasarkan hasil penelitian [3] peningkatan displasemen tersebut harus dibayar dengan peningkatan hambatan hingga hampir 4 kali lipatnya. Tentunya hal ini menjadi kabar buruk bagi para nelayan karena kebutuhan konsumsi bahan bakar kapal mereka juga meningkat.

Penelitian lain telah dilakukan oleh [4] untuk mengurangi hambatan kapal Laganbar yaitu dengan memodifikasi bentuk lambung demihull kapal dengan metode Luckenby. Metode tersebut mengubah bentuk CSA kapal untuk membentuk lambung kapal baru. Metode ini berhasil mengurangi hambatan total kapal sebesar 6,5\%. Metode tersebut juga telah sukses digunakan [5] untuk meningkatkan kualitas olah gerak kapal katamaran.

Penelitian lain untuk mengurangi hambatan kapal katamaran telah dilakukan oleh beberapa peneliti dengan menggunakan konsep centerbulb. Centerbulb adalah bulbous (tonjolan) yang ada pada kapal katamaran yang berada diantara 2 lambung kapal katamaran (ditengah-tengah). Tujuan dari pemasangan centerbulb ini adalah untuk meberikan interferensi gelombang diantara 2 lambung katamaran. Ketika gelombang berinterferensi diharapkan gelombang akan pecah dan mengurangi hambatan gelombang. Selain mengurangi hambatan kapal aplikasi centerbulb juga dapat meningkatkan kualitas seakeeping kapal katamaran [6, 7].

Pada penelitian [8], centerbulb yang digunakan beukuran besar dan diletakkan pada posisi depan dan belakang seperti pada Gambar 1. Hasil penelitian tersebut meberian rekomendasi bahwa hambatan gelombang pada kapal katamaran dengan centerbulb tergantung dari interaksi hambatan gelombang kapal katamaran tersebut, ukuran centerbulb dan posisi centerbulb terhadap lambung kapal katamaran.

Pada penelitian yang lain, Zotti [7] meberikan fin pada centerbulb untuk meneliti pengaruhnya terhadap hambatan dan olah gerak kapal (Gambar 2). Hasil penelitian tersebut adalah centerbulb dengan fin mengurangi hambatan kapal pada $\mathrm{Fr}>0,3$ dan meningkatkan hambatan pada $\mathrm{Fr}<0,3$. Puncak kurva RAO dari heaving dan pithing centerbulb dengan fin menjadi turun dibandingkan dengan katamaran tanpa centerbulb. Hal ini mengindikasikan centerbulb dengan fin memberikan dampak positif terhadap olah gerak kapal.

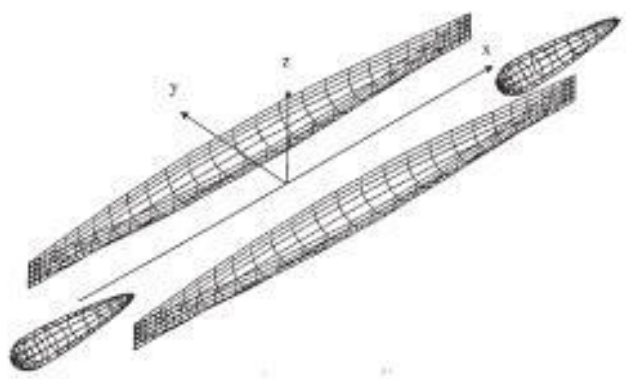

Gambar 1. Centerbulb Pada Kapal katamaran Saha et. al. [8]

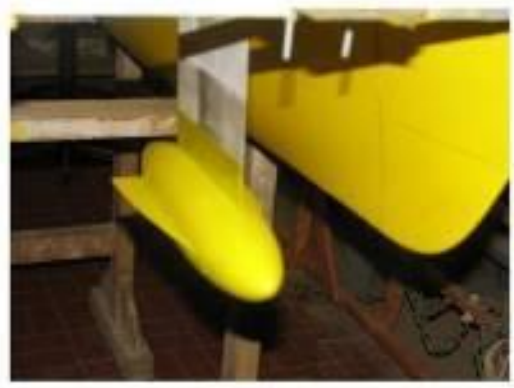

(a)

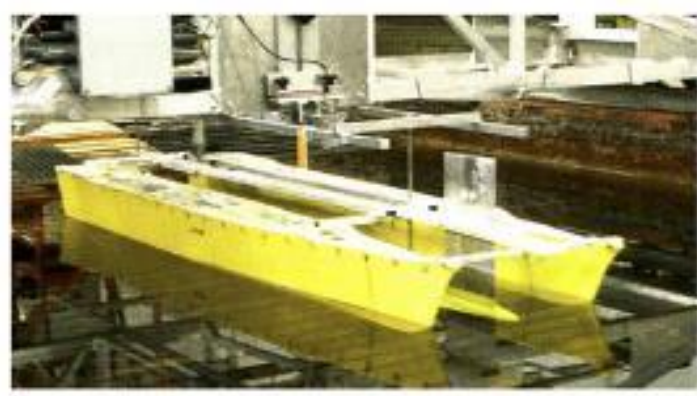

(b)

Gambar 2. Centerbulb Pada Kapal Katamaran Zotti [7].

(a) Bentuk Centerbulb Menggunakan Fin. (b) Bentuk

Centerbulb Menggunakan Fin Ketika Dipasang di Kapal

\section{Katamaran}

Danisman [9] melakukan optimasi posisi dan geometri centerbulb yang berbentuk elipsoidal (Gambar 3). Penelitian tersebut telah berhasil mengurangi hambatan gelombang kapal sebesar 15\% berdasarkan hasil perhitungan numerik dan $13 \%$ berdasarkan hasil pengujian eksperimen di towing tank. Metode Artificial Neural Networks (ANN) digunakan untuk mengoptimasi dimensi centerbulb yang berupa elipsoidal dan posisi centerbulb. Hasil penelitian ini mengurangi hambatan gelombang kapal sebesar $15 \%$ berdasarkan hasil perhitungan numerik dan $13 \%$ berdasarkan hasil pengujian eksperimen di towing tank. 


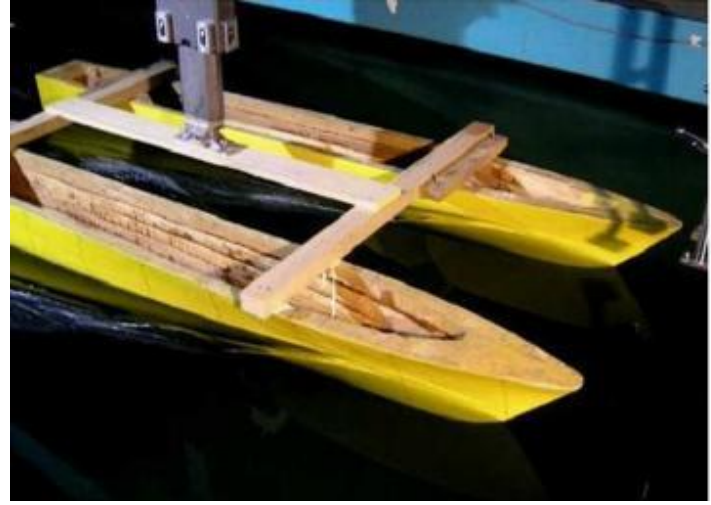

(a)

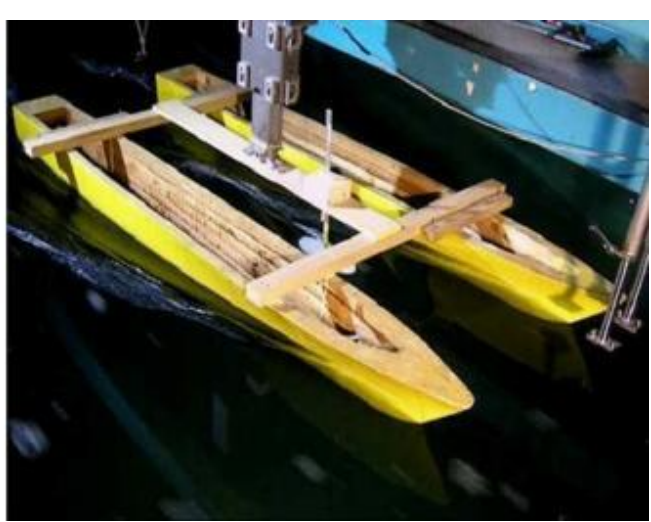

(b)

Gambar 3. Pengujian Eksperimen Katamaran Tanpa (a) Dan Dengan Centerbulb (b) Danisman [9].

Pada penelitian ini, bentuk centerbulb yang berupa elipsoidal akan diganti menjadi bentuk foil. Bentuk ini diduga akan lebih mengurangi hambatan kapal karena bentuk belakang foil yang meruncing akan membuat pola aliran menjadi streamline dan tidak akan menimbulkan vortex shading atau ulekan seperti ketika aliran melewati bentuk lingkaran atau elipsoid. Tujuan dari penelitian ini adalah untuk mengetahui pengaruh posisi centerbulb terhadap komponen hambatan kapal.

\section{Metode}

\section{Objek Penelitian}

Objek dari penelitian adalah kapal ikan yang didapat dari hasil survey lapangan pada salah satu kapal katamaran nelayan tradisional di Cilacap, yaitu MV. Laganbar. Pada saat perhitungan pada software CFD model kapal diskala dengan perbandingan 1:10. Perbandingan ukuran ukuran asli dan model skala terdapat pada Tabel 1. Gambar kapal katamaran terdapat pada Gambar 4. Kecepatan kapal yang akan diuji pada penelitian ini adalah pada nilai Froude Number, Fr 0,15-0,35.

Tabel 1. Data Ukuran Utama Kapal

\begin{tabular}{|l|c|c|}
\hline \multirow{2}{*}{ Parameter } & \multicolumn{2}{|c|}{ Nilai } \\
\cline { 2 - 3 } & Ukuran Asli & Model Skala \\
\hline Panjang Garis Air (LWL) & $8,90 \mathrm{~m}$ & $0,89 \mathrm{~m}$ \\
\hline Sarat (T) & $0,50 \mathrm{~m}$ & $0,05 \mathrm{~m}$ \\
\hline Tinggi (H) & $0,80 \mathrm{~m}$ & $0,08 \mathrm{~m}$ \\
\hline Lebar Demi Hull (B) & $1,10 \mathrm{~m}$ & $0,11 \mathrm{~m}$ \\
\hline Lebar Keseluruhan (BOA) & $3,40 \mathrm{~m}$ & $0,34 \mathrm{~m}$ \\
\hline
\end{tabular}

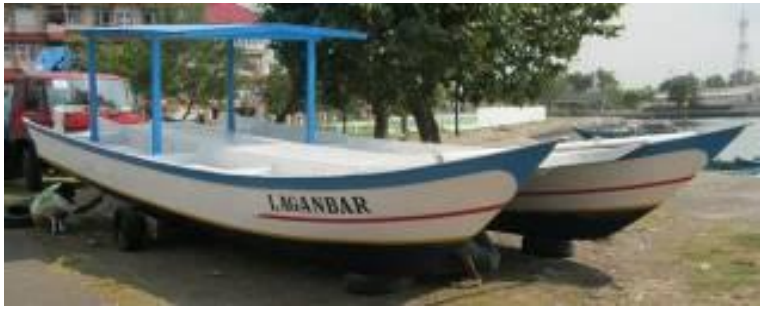

(a)

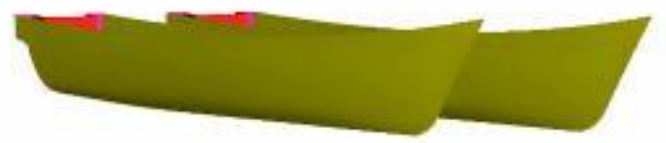

(b)

Gambar 4. Kapal Catamaran M.V. Laganbar (a) dan Model

3D Kapal (b)

\section{Penyesuaian Centerbulb}

Bentuk geometri elipsoidal centerbulb yang ada pada kapal Danisman [9] perlu disesuaikan dengan kapal Laganbar dengan cara membandingkan panjang lebar dan tinggi centerbulb terhadap panjang, lebar dan sarat kapal. Adapun ukuran utama dan model kapal Danisman [9] terdapat pada Tabel 2 dan Gambar 5. Sedangkan ukuran serta perhitungan perbandingan dimensi centerbulb terdapat pada Tabel 3. Perbandingan tersebut digunakan untuk menentukan geometri centerbulb berbentuk foil.

Tabel. 2. Ukuran Utama Kapal Danisman [9]

\begin{tabular}{|c|c|c|}
\hline Parameter & Ukuran Asli & Model Skala \\
\hline $\mathrm{Lwl}$ & $25,25 \mathrm{~m}$ & $2,525 \mathrm{~m}$ \\
\hline $\mathrm{B}$ & $2,6 \mathrm{~m}$ & $0,26 \mathrm{~m}$ \\
\hline $\mathrm{T}$ & $1,4 \mathrm{~m}$ & $0,14 \mathrm{~m}$ \\
\hline $\mathrm{Cb}$ & 0,41 & 0,41 \\
\hline
\end{tabular}




\begin{tabular}{|c|c|c|}
\hline $\begin{array}{c}\text { Dimensi } \\
\text { Elipsoidal } \\
\text { Centerbulb } \\
\text { Danisman [9] }\end{array}$ & Perbandingan & $\begin{array}{c}\text { Dimensi } \\
\text { Elipsoidal } \\
\text { Centerbulb } \\
\text { Kapal Laganbar }\end{array}$ \\
\hline $\begin{array}{c}\text { Panjang }(\mathrm{a})=1,41 \\
\mathrm{~m} \\
\text { Lebar }(\mathrm{b})=0,62 \mathrm{~m} \\
\text { Tinggi }(\mathrm{c})=0,34 \\
\mathrm{~m}\end{array}$ & $\begin{array}{c}1,41 / 25,25= \\
0,0558 \\
0,62 / 2,6=0,2384 \\
0,34 / 1,4=0,2428\end{array}$ & $\begin{array}{c}\text { Panjang (a) }= \\
0,486 \mathrm{~m} \\
\text { Lebar }(\mathrm{b})=0,241 \\
\mathrm{~m} \\
\text { Tinggi }(\mathrm{c})=0,121 \\
\mathrm{~m}\end{array}$ \\
\hline
\end{tabular}

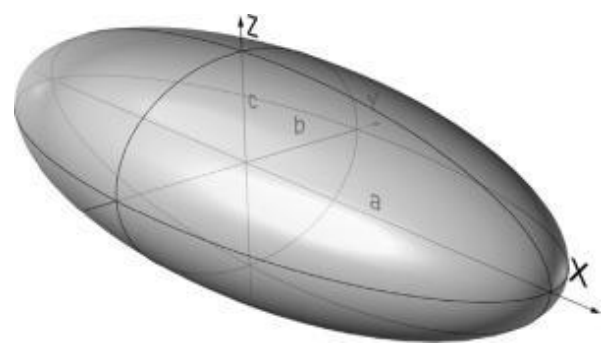

Gambar 5. Geometri Elipsoidal Centerbulb Danisman [9]

\section{Centerbulb Berbentuk Foil}

Bentuk foil yang akan digunakan dalam penelitian ini adalah NACA 0030. Bentuk ini adalah bentuk foil simetris yang mempunyai nilai maksimum chamber $30 \%$ dari panjang foil. Pada Tabel 3 panjang centerbulb untuk kapal Laganbar adalah 0,486 m, sehingga lebar dan tinggi centerbulb berbentuk foil adalah $30 \%$ dari 0,486 yaitu $0,1458 \mathrm{~m}$. Bentuk foil NACA 0030 terdapat pada Gambar 6.

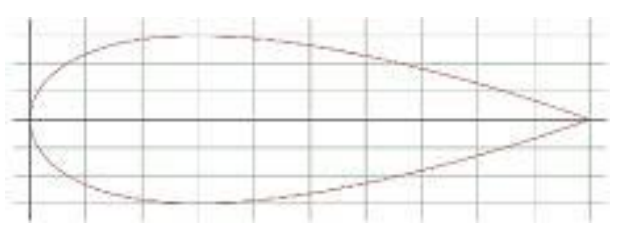

Gambar 6. Bentuk Foil NACA 0030

\section{Posisi Centerbulb}

Posisi centerbulb divariasikan terhadap panjang dan sarat kapal. Posisi terhadap panjang kapal dibagi menjadi 3 bagian, belakang $(10 \% \mathrm{Lwl})$ tengah $(50 \%$ Lwl) dan depan (90\% Lwl). Posisi terhadap sarat kapal juga dibagi menjadi 3 bagian, bawah (30\% T) tengah $(50 \% \mathrm{~T})$ dan atas $(70 \% \mathrm{~T})$. Penentuan posisi centerbulb dapat dilihat pada Tabel 4 dan Gambar 7.

Tabel 4. Posisi Centerbulb (m)

\begin{tabular}{|c|c|c|c|}
\hline Model & $\begin{array}{c}\text { Posisi } \\
\text { Memanjang } \\
(\mathbf{x})\end{array}$ & $\begin{array}{c}\text { Posisi } \\
\text { Melintang } \\
(\mathbf{y})\end{array}$ & $\begin{array}{c}\text { Posisi } \\
\text { Vertikal } \\
(\mathbf{z})\end{array}$ \\
\hline Awal & \multicolumn{3}{|c|}{ Tanpa Centerbulb } \\
\hline 1 & 8,1 & 0 & 0,12 \\
\hline 2 & 8,1 & 0 & 0,235 \\
\hline 3 & 8,1 & 0 & 0,35 \\
\hline 4 & 4,5 & 0 & 0,12 \\
\hline 5 & 4,5 & 0 & 0,235 \\
\hline 6 & 4,5 & 0 & 0,35 \\
\hline 7 & 0,9 & 0 & 0,12 \\
\hline 8 & 0,9 & 0 & 0,235 \\
\hline 9 & 0,9 & 0 & 0,35 \\
\hline
\end{tabular}

\section{Perhitungan Hambatan Kapal Menggunakan CFD}

Software CFD yang digunakan adalah Tdyn versi 12.2.3.0. Salah satu tahap pada pre processor atau tahap set up adalah penentuan domain fluida (Gambar 8) dimana ukuran pada sumbu memanjang ( $x$ ) pada bagian belakang kapal berukuran $3 \times \mathrm{L}$ dan di depan kapal berukuran $2 \mathrm{x}$ L. Untuk sumbu melintang (y) berukuran masing-masing $2 \times$ L pada kiri dan kanan kapal. Sedang sumbu vertikal (z) berukuran $20 \mathrm{x} \mathrm{T}$ (sarat kapal).

Selanjutnya adalah penentuan Materials and Properties, yaitu penentuan spesifikasi fluida yang akan dianalisis. Volume yang berada dalam domain fluida dianggap sebagai fluida dengan mengisi massa jenis air $1025 \mathrm{~kg} / \mathrm{m}^{3}$ dan kekentalan jenis 0,001025 $\mathrm{kg} / \mathrm{m} . \mathrm{s}$. Setup selanjutnya adalah Initial Condition Data, yaitu pengaturan pada masing-masing Boundary Condition di domain fluida tersebut. Pengaturan tersebut meliputi freesurface, wall, inlet dan bottom surface, outlet, dan pengaturan permukaan lambung (wall/bodies).

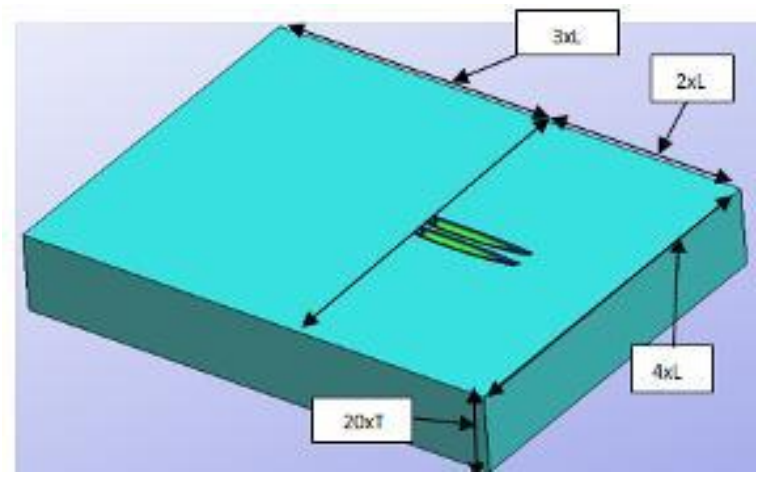

Gambar 8. Boundary Layer dan Model Kapal 

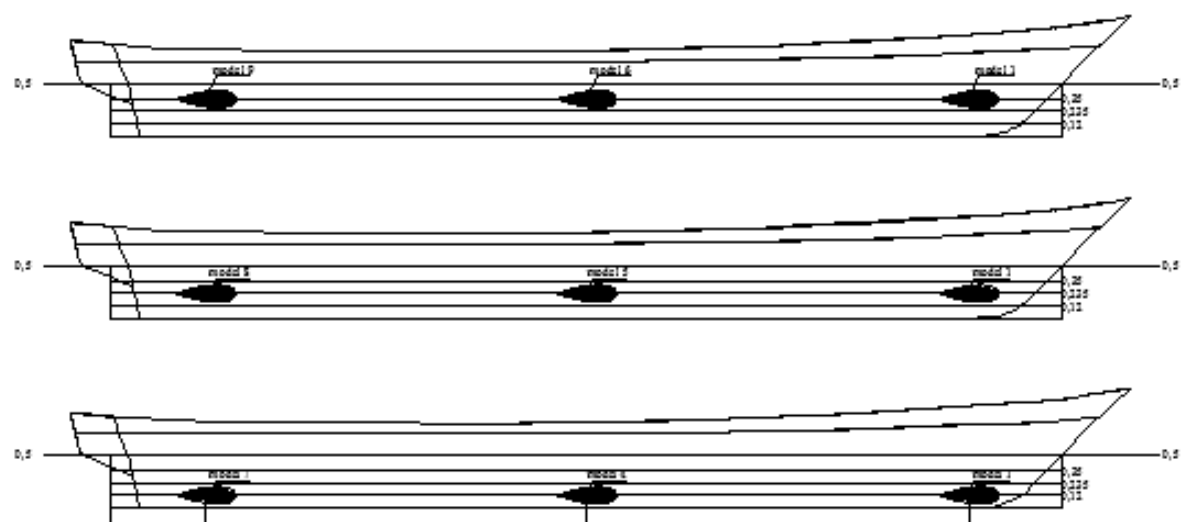

Gambar 7. Posisi Centerbulb

Pengaturan kecepatan kapal terdapat pada menu initial and condition data dan submenu initial and field data. Input besarnya kecepatan pada sumbu x. Selanjutnya pada tahap Modules Data diatur pemilihan model turbulence. Pada penelitian ini model turbulence yang digunakan adalah K_Omega_SST. Tahap berikutnya adalah pembuatan Meshing Data. Bentuk unstructured mesh digunakan pada penelitian ini dengan ukuran mesh 0,01 untuk daerah kapal dibawah air, 0,05 untuk freesurface, 0,1 untuk seluruh komponen sisa kecuali Centerbulb 0,005. Hasil mesh dapat dilihat pada Gambar 9.

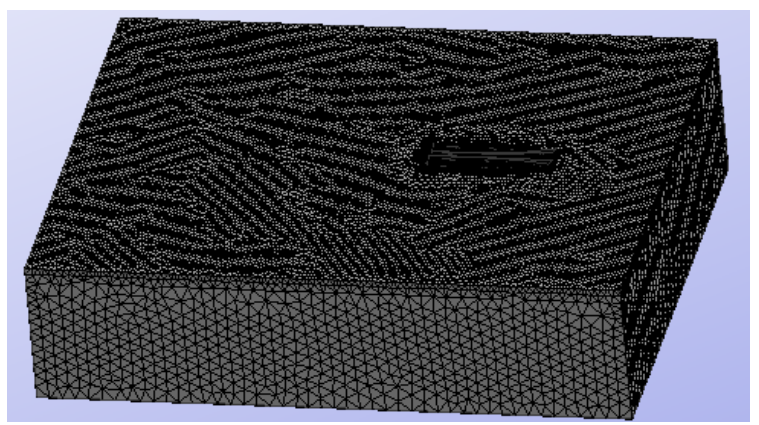

Gambar 9. Hasil Meshing

\section{Validasi Hasil Perhitungan CFD}

Standar untuk menghitung hambatan total kapal terdapat pada Persamaan 1. dimana $\rho$ adalah massa jenis air laut $1050 \mathrm{~kg} / \mathrm{m}^{3}$, v adalah kecepatan kapal dalam $\mathrm{m} / \mathrm{s}$, WSA adalah luas permukaan basah kapal dalam $\mathrm{m}^{2}$ dan $\mathrm{C}_{\mathrm{T}}$ adalah koefisien hambatan kapal. Perbedaan komponen koefisien hambatan total $\left(\mathrm{C}_{\mathrm{T}}\right)$ katamaran dengan kapal monohull terdapat pada interferensi dari masing-masing komponen hambatan kapal yang disebabkan karena interaksi dari 2 lambung tersebut. Interferensi adalah perbandingan masing-masing komponen hambatan katamaran terhadap $2 \mathrm{x}$ komponen hambatan demihullnya. Interferensi dari masing-masing komponen hambatan kapal katamaran terdapat pada Persamaan 2.

$$
\begin{gathered}
R_{T}=\frac{1}{2} \cdot \rho \cdot v^{2} \cdot W S A \cdot C_{T} \\
C_{T}=(1+\phi k) \sigma C f+\tau C w \\
C_{T}=(1+\beta k) C f+\tau C w
\end{gathered}
$$

dimana $\phi$ adalah interferensi hambatan bentuk, $\sigma$ adalah interferensi hambatan viskos dan $\tau$ adalah interferensi hambatan gelombang. Untuk tujuan praktis [10] mengkombinasikan $\varnothing$ dan $\sigma$ kedalam interferensi hambatan viskos (viscous), yakni faktor $\beta$, dimana $(1+\varphi \mathrm{k}) \sigma=(1+\beta \mathrm{k})$ seperti pada Persamaan 3 . Sedangkan faktor interferensi hambatan gelombang (wave-making), $\tau$, dapat diperoleh dari hasil eksperimen atau hasil pengurangan antara total hambatan dan hambatan viskos [11].

Jamaluddin [12] meneliti mengenai interferensi dari masing-masing komponen hambatan kapal katamaran. Hasil penelitian tersebut mendapatkan formula empisris untuk menentukan nilai masingmasing interferensi hambatan kapal katamaran. Disamping itu [12] juga memodifikasi formula Molland untuk menentukan faktor bentuk kapal katamaran $(1+\beta \mathrm{k})$ dengan menambah variabel $\mathrm{S} / \mathrm{L}$. Formula empiris hasil pernelitian [12] terdapat pada Persamaan $4-12$.

$$
\begin{aligned}
& \phi=0,00006(S / L)+0,998 \\
& \sigma=1,008 e^{-3(S / L)} \\
& (1+\beta \mathrm{k})=3,03\left(L / \mathrm{Vol}^{1 / 3}\right)^{-0,4} \\
& +0,016(S / L)^{-0,65} \\
& \tau=0,068(S / L)^{-1,38} \quad \text { Pada Fr 0,19 } \\
& \tau=0,359(S / L)^{-0,87} \quad \text { Pada Fr 0,28 } \\
& \tau=0,574(S / L)^{-0,33} \quad \text { Pada Fr 0,37 } \\
& \tau=0,790(S / L)^{-0,14} \quad \text { Pada Fr 0,47 } \\
& \tau=0,504(S / L)^{-0,31} \quad \text { Pada Fr 0,56 } \\
& \tau=0,501(S / L)^{-0,18} \quad \text { Pada Fr 0,65 }
\end{aligned}
$$




\section{Hasil dan Pembahasan}

\section{Hasil Validasi}

Hasil perhitungan hambatan kapal katamaran tanpa centerbulb dengan metode CFD divalidasikan dengan hasil perhitungan hambatan dengan metode empiris sesuai pada Persamaan $6-12$. Validasi dilakukan untuk memastikan bahwa set up yang dilakukan sudah benar. Pada Gambar 10 dapat dilihat bahwa hasil CFD mempunyai kesamaan hasil dengan empiris. Error dari masing-masing kecepatan adalah $1 \%$ hingga $4 \%$ dimana error ini termasuk kecil sehingga set up tersebut bisa digunakan pada model model lainnya.

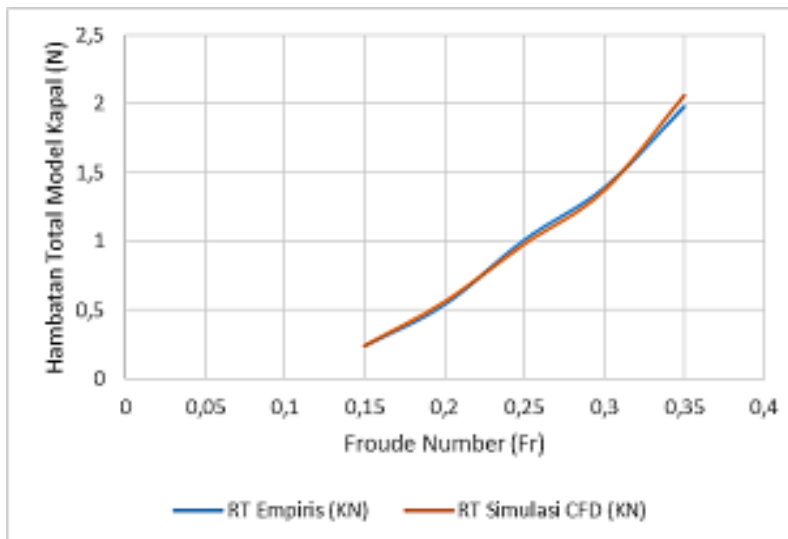

Gambar 10. Validasi CFD dengan Empiris

\section{Pengaruh Posisi Centerbulb Terhadap Hambatan Total}

Hasil perhitungan hambatan kapal berdasarkan Computational Fluid Dynamic Tdyn 12.2.3.0 untuk Froude Number (Fr) 0,15, 0,20, 0,25, 0,30 dan 0,35 disajikan pada Tabel 5. Dari Tabel tersebut diperoleh nilai hambatan total dari seluruh konfigurasi model. Konfigurasi model masih menambah hambatan total model original pada Fr 0,15 sampai Fr 0,30. Tetapi mengurangi pada Fr 0,35. Hambatan total pada Fn 0,35 terkecil terdapat pada Model 6 (Gambar 12).

Tabel 5 dan Gambar 11 adalah grafik perbandingan hambatan total model original dengan model terbaik yaitu Model 6. Berdasarkan perbandingan tersebut kecepatan efektif kapal dengan penambahan centerbulb berbentuk foil berada pada Fr 0,32 karena pada Fr tersebut hambatan total kapal berkurang.

Pada Gambar 13 elevasi gelombang yang terbentuk akibat kapal melaju pada Fr 0,35 berdasarkan hasil CFD disajikan. Dapat dilihat bahwa bentuk tinggi permukaan air di belakang kapal lebih rendah yang menandakan bahwa hambatan gelombang kapal lebih rendah dibandingkan dengan model awal. Hal ini disebabkan karena terjadi superposisi antara gelombang yang ditimbulkan oleh kedua lambung demihull katamaran dan centerbulb itu sendiri sehingga tinggi permukaan gelombang menjadi lebih rendah

\begin{tabular}{|c|c|c|c|c|c|}
\hline Model & $\begin{array}{c}\mathrm{Fr} \\
0,15\end{array}$ & $\begin{array}{c}\mathbf{F r} \\
\mathbf{0 , 2 0}\end{array}$ & $\begin{array}{c}\mathrm{Fr} \\
\mathbf{0 , 2 5}\end{array}$ & $\begin{array}{c}\mathbf{F r} \\
\mathbf{0 , 3 0}\end{array}$ & $\begin{array}{c}\mathbf{F r} \\
\mathbf{0 , 3 5}\end{array}$ \\
\hline Awal & 0,24 & 0,56 & 0,98 & 1,37 & 2,06 \\
\hline 1 & 0,25 & 0,70 & 1,25 & 1,76 & 1,79 \\
\hline 2 & 0,23 & 0,75 & 1,17 & 1,65 & 1,49 \\
\hline 3 & 0,23 & 0,78 & 1,23 & 1,73 & 1,41 \\
\hline 4 & 0,23 & 0,70 & 1,17 & 1,66 & 1,50 \\
\hline 5 & 0,21 & 0,74 & 1,17 & 1,66 & 1,41 \\
\hline 6 & 0,25 & 0,74 & 1,17 & 1,67 & 1,37 \\
\hline 7 & 0,24 & 0,72 & 1,24 & 1,75 & 1,97 \\
\hline 8 & 0,25 & 0,73 & 1,24 & 1,75 & 1,92 \\
\hline 9 & 0,23 & 0,77 & 1,21 & 1,71 & 1,80 \\
\hline
\end{tabular}

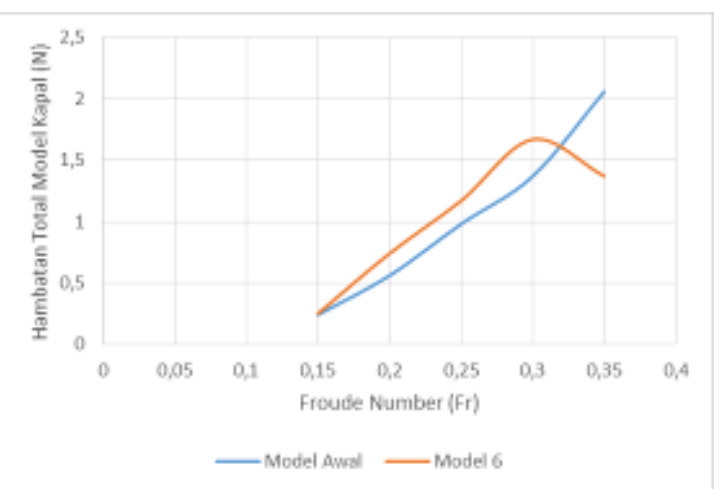

Gambar 11. Grafik Perbandingan Hambatan Model terbaik

Gambar 12. Model 6 (Posisi memanjang Centerbulb 4,5 m

dan posisi tegak Centerbulb $0,35 \mathrm{~m}$ ) 


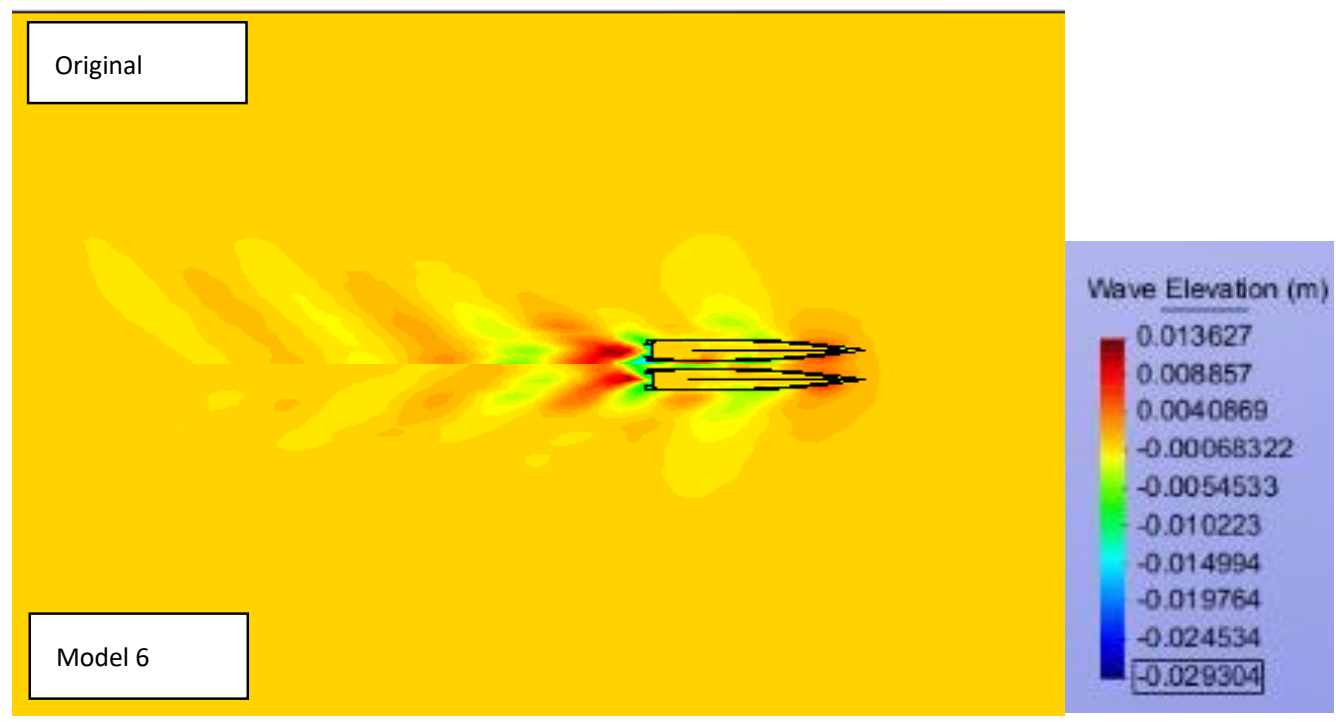

Gambar 13. Perbandingan Contour model original (atas) dan model 6 (bawah)

\section{Hambatan Viskositas dan Hambatan Gelombang}

Kompenen hambatan total kapal terdiri dari 2 komponen yaitu hambatan viskos yang arah gayanya tangensial (singgung) dan hambatan gelombang yang arah gayanya tegak lurus. Berdasarkan Tabel 6 dan Gambar 14, penambahan centerbulb menambah hambatan viskositas meskipun tidak signifikan. Panambahan ini disebabkan karena adanya centerbulb yang mengakibatkan luas permukaan kapal (WSA) yang bergesekan dengan fluida bertambah.

Di sisi lain, penggunaan centerbulb menambah hambatan gelombang hingga pada Fr 0,3. Pada Fr 0,4 penggunaan centerbulb mulai efektif. Hambatan gelombang dapat berkurang hingga $47 \%$. Interferensi gelombang yang terjadi di antara kedua lambung dapat berkurang dengan adanya centerbulb. Hal ini sesuai dengan hasil penelitian Danisman [9] dimana pada kecepatan rendah penggunaan centerbulb tidak efektif. Karena pada kecepatan rendah, komponen hambatan kapal didominasi oleh hambatan viskos. Sehingga keberadaan centerbulb hanya akan menambah hambatan kapal.

Namun pada kecepatan tinggi, gelombang yang ditimbulkan akibat gerakan kapal muncul, sehingga hambatan gelombang pun mulai meningkat. Disaat kecepatan inilah centerbulb bekerja, yaitu memecah gelombang yang ditimbulkan oleh badan kapal dengan gelombang yang ditimbulkan oleh centerbulb itu sendiri. Kedua gelombang akan saling bertabrakan dan menghasilkan amplitudo gelombang yang lebih rendah.
Tabel 6. Hasil Penambahan Hambatan

\begin{tabular}{|c|c|c|c|c|c|c|}
\hline Fr & $\begin{array}{c}\text { RW } \\
\text { Original }\end{array}$ & $\begin{array}{c}\text { RW } \\
\text { Model } \\
6\end{array}$ & Selisish & $\begin{array}{c}\text { RV } \\
\text { Original }\end{array}$ & $\begin{array}{c}\text { RV } \\
\text { Model } \\
6\end{array}$ & Selisih \\
\hline 0,15 & 0,10 & 0,09 & $-3 \%$ & 0,14 & 0,16 & $9 \%$ \\
\hline 0,20 & 0,31 & 0,49 & $57 \%$ & 0,24 & 0,25 & $2 \%$ \\
\hline 0,25 & 0,61 & 0,80 & $30 \%$ & 0,36 & 0,37 & $2 \%$ \\
\hline 0,30 & 0,90 & 1,18 & $32 \%$ & 0,47 & 0,49 & $3 \%$ \\
\hline 0,35 & 1,44 & 0,77 & $-47 \%$ & 0,62 & 0,60 & $-4 \%$ \\
\hline
\end{tabular}

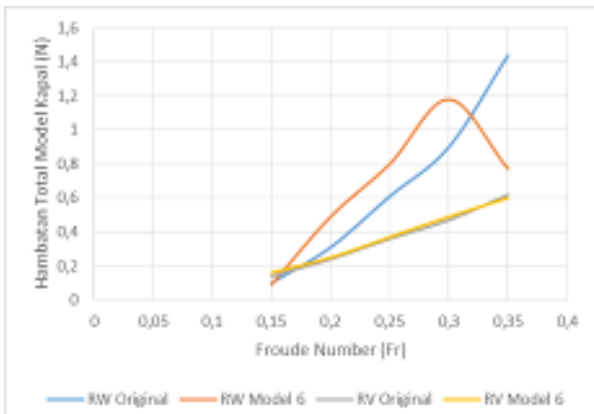

Gambar 14. Perbandingan Komponen Habatan Kapal Katamaran Model Original dan Model 6 (terbaik)

\section{Kesimpulan}

Dari kesembilan konfigurasi posisi centerbulb, Model 6 merupakan model terbaik karena Pada Fr 0,35 dapat mengurangi hambatan kapal hingga 33\%. Untuk komponen hambatan viskos tidak terlalu terpengaruh secara signifikan terhadap penggunaan centerbulb. Namun pada komponen hambatan gelombang, penggunaan centerbulb ini dapat mengurangi hambatan gelombang sebesar $47 \%$ pada Fr 0,35 . 


\section{Daftar Pustaka}

[1] M. S. Seif dan E. Amini, "Performance Comparison Between Planing Monohull and Catamaran at High Froude Numbers," Iranian Journal of Science \& Technology, vol. 28, no. B4, 2004.

[2] F. Zouridakis, "A Preliminary Design Tool for Resistance and Powering Prediction of Catamaran Vessels," Master Thesis Massachusetts Institute of Technology. Dept. of Ocean Engineering. , 2005.

[3] Samuel, M. Iqbal dan I. K. A. P. Utama, "An Investigation Into The Resistance Components Of Converting A Traditional Monohull Fishing Vessel Into Catamaran Form," International Journal of Technology, vol. 6, no. 3, pp. 432441, 2015.

[4] M. Iqbal dan Samuel, "Traditional Catamaran Hull Form Configurations That Reduce Total Resistance," International Journal of Technology, vol. 8, no. 1, pp. 989-997, 2017.

[5] M. Iqbal dan G. Rindo, "Optimasi Bentuk Demihull Kapal Katamaran Untuk Meningkatkan Kualitas Seakeeping," KAPAL : Jurnal Ilmu Pengetahuan dan Tekologi Kelautan, vol. 12, no. 1, pp. 19-24, 2015.

[6] D. Bruzzone, A. Grasso dan I. Zotti, "Nonlinear Seakeeping Analysis of Catamarans with Central Bulb," Naples, 2008.

[7] I. Zotti, "Medium Speed Catamaran with Large Centralbulbs: Experimental Investigation on Resistance and Vertical Motions," Naples, 2007.

[8] G. K. Saha, K. Suzuki dan H. Kai, "Hydrodynamic Optimization of a Catamaran Hull With Large Bow and Stern Bulbs Installed on the Center Plane of the Catamaran," Journal of Marine Science and Technology, vol. 10, pp. 32-40, 2005.

[9] D. B. Danisman, "Reduction of Demi-Hull Wave Interference Reistance in Fast Displacement Catamarans Utilizing an Optimized Centerbulb Concept," Ocean Engineering, vol. 91, pp. 227-234, 2014.

[10] M. Insel dan A. F. Molland, "An Investigation into the Resistance Components of High Displacement Catamarans," Transaction Royal Institutions of Naval Architevture, vol. 134, 1992.

[11] A. F. Molland, A Guide to Ship Design, Construction and Operation, The Maritime Engineering Reference Book, ButterworthHeinemann, Elsevier, 2008.

[12] A. Jamaluddin, I. K. A. P. Utama, B. Widodo dan A. F. Molland, "Experimental and Numerical Study of the Resistance Component
Interactions of Catamarans," Proceedings of the Institution of Mechanical Engineers, Part M: Journal of Engineering for the Maritime Environment, vol. 227, no. 1, pp. 51-60, 2012.

[13] S. A. Harvald, Resistance and Propulsion of Ships, New York : Wiley, 1983. 